\title{
The Relation between Gender, Reasons to Participate in STEM-Related Subjects, Programs and the University Supports on First-Year University Student's Satisfaction: A Structural Equation Model
}

\author{
Ikmanda Nugraha1*, Tatang Suranto ${ }^{2}$, Asep Kadarohman 3 , Ari Widodo ${ }^{4}$, Gusti Darmawan ${ }^{5}$ \\ ${ }^{1}$ Department of Science Education, Universitas Pendidikan Indonesia, Bandung, Indonesia \\ ${ }^{2}$ Elementary School Teacher Study Program, Universitas Pendidikan Indonesia, Serang, Indonesia \\ ${ }^{3}$ Department of Chemistry Education, Universitas Pendidikan Indonesia, Bandung, Indonesia \\ ${ }^{4}$ Department of Biology Education, Universitas Pendidikan Indonesia, Bandung, Indonesia \\ ${ }^{5}$ School of Education, The University of Adelaide, Adelaide, Australia \\ *Corresponding Author. ikmandanugraha@upi.edu
}

\begin{abstract}
First-year student's satisfaction has considered an important factor in the quality education offered by the university program. The objective of this study is to investigate the relationship among gender, a reason to participate in STEM-related subjects, program, and the university support on first-year student's satisfaction of STEM learning. The methods used in this study surveyed student's satisfaction using adapted interest and recruitment in the science questionnaire (IRIS Q) instrument. The questionnaire comprised question items covering school science experiences, sources of inspiration for the choice of education, expectations for future job, first-year experiences as a STEM student, and attitudes to gender equity in STEM. A total of 448 students, first-year students from STEM-related programs, have participated voluntarily in this study. The structural equating model assisted by computer program IBM SPSS Amos 20 was employed to analyze the hypothesized model. The results from the model showed that reason and university support have a positive direct effect on first-year students' satisfaction with STEM learning. From this study, it is suggested for the university to improve first-year student's satisfaction by helping STEM students to develop appropriate expectations of the program, facilitating teaching quality to meet STEM students' learning, and assisting students in developing positive attitudes toward their future carriers.
\end{abstract}

Keywords Structural equation model, STEM learning, first-year university students, satisfaction student's satisfaction.

\section{INTRODUCTION}

In higher education, the issues of student satisfaction have been a great concern among researchers, policymakers, and practitioners. The point of student's satisfaction has become the major concern of many research, and the majority of the studies agreed that student's satisfaction has a strong correlation with university supports (e.g., Crisp et al., 2009; Duong, 2015; Green, Hood, \& Neumann, 2015; Gruber, Fuß, Voss, \& Gläser-Zikuda, 2010; Hakim, 2014; Josephat, Ismail, \& Martin, 2014; Li \& Carroll, 2017; Lo, 2010; Mehdipour \& Zerehkafi, 2013; Möller, 2006; Naaj, Nachouki, \& Ankit, 2012). Most of the finding discuss that student's satisfaction can be used as the indicators to identify the areas where the university are performing well. Moreover, it can use for performing strategies to retain and fit the students, providing insights or reputation of the university from people, and providing feedback for future program planning (Billups, 2008).

The first-year student becomes the concern because, this year, the student will decide whether they will stay or leave in STEM-related subjects. In the middle of various issue related to the reducing interest of students to participate in science, technology, engineering and mathematics (STEM) related subjects, the issue of lack of teaching quality come to the surface as one of the determinants of student's satisfaction. In the United Kingdom, students from STEM programs satisfied with funding and supporting facilities, but they were unsatisfied with the STEM teaching. In contrast, students from nonSTEM programs experienced different directions (Pawson,

Received: 12 December 2019

Revised: 5 March 2020

Published: 19 March 2020 
2012). Because teaching practices are context-specific (Shulman, 1987), it is evident that certain teaching practices are common in a university STEM teaching but different from another social discipline. Moreover, students in a university STEM classroom probably have different learning needs compared to students in different subject areas, such as laboratory activities or site visits (Chang \& Park, 2014). This finding has encouraged STEM teaching to satisfy the students expectation because teaching quality and expertise showed the most reliable relationship with student's satisfaction and their learning outcomes (Green, Hood, \& Neumann, 2015; Hakim, 2014; Lo, 2010; Suarman, Aziz, \& Yasin, 2013; Burgess, Senior, Moores, 2018; Khalil-Ur-Rehman, Farooq, \& Younas, 2018; Son, Ha, Thi, \& Khuyen, 2018).

In terms of lecturer-student interaction, the study from a university in Australia found that students expect the university to provide learning resources that can be accessed by the students anytime and anywhere. Lectures need to engage students in interactive activities, student works must be read and give feedback, and the assessment marked and returned to them (Crisp et al., 2009). On the other hand, the university's core service, i.e., the lecture, including the attainment of knowledge, class notes and materials, and classroom delivery, are more important than the physical aspects of the University services (Douglas, Douglas, \& Barnes, 2006).

Another study showed different findings such as (1) students' satisfaction with their university is based on a relatively stable person-environment relationship (Gruber, Fuß, Voss, \& Gläser-Zikuda, 2010), (2) college curriculum needs to meet the student's expectation (Zhou, 2016), (3) physical facilities and staff responsiveness also play an important role for student's satisfaction (Ahmed \& Masud, 2014), (4) gender play different perspective, female students put higher expectation and demanding on the importance of university services than male students (Grebennikov \& Skaines, 2009), (5) gender and the program do not have a significant influence on student's satisfaction (Elhadary, 2016a), (6) a sense of belonging, and citizenship knowledge and skills were the best determinants of the level of first-year student satisfaction (Al-Sheeb, B., Hamouda, A. M., \& Abdella, G. M. (2018). To sum up, it should also be noted that student satisfaction results not only from quality in teaching and learning, but it also comes from total student's experiences in their study (Wilkins, Balakrishnan, \& Huisman, 2012). Therefore, to study student satisfaction, many other factors must come into consideration, such as ethnographic information, motives, assessment and Feedback, learning resources, facilities, social life, etc.

Based on the literature above, the author formulated the following hypothesized model (Figure 1) that describes the determinants of student satisfaction. Accordingly, the author hypothesizes that the following factors will have a positive direct effect on student satisfaction: 1) gender, 2) reason to participate in STEM-related subjects, 3) programs, and 4) university support. All the factors are included in the hypothesized model because they have the possibility to become the determinants of student satisfaction. Using Structural Equation Model (SEM)

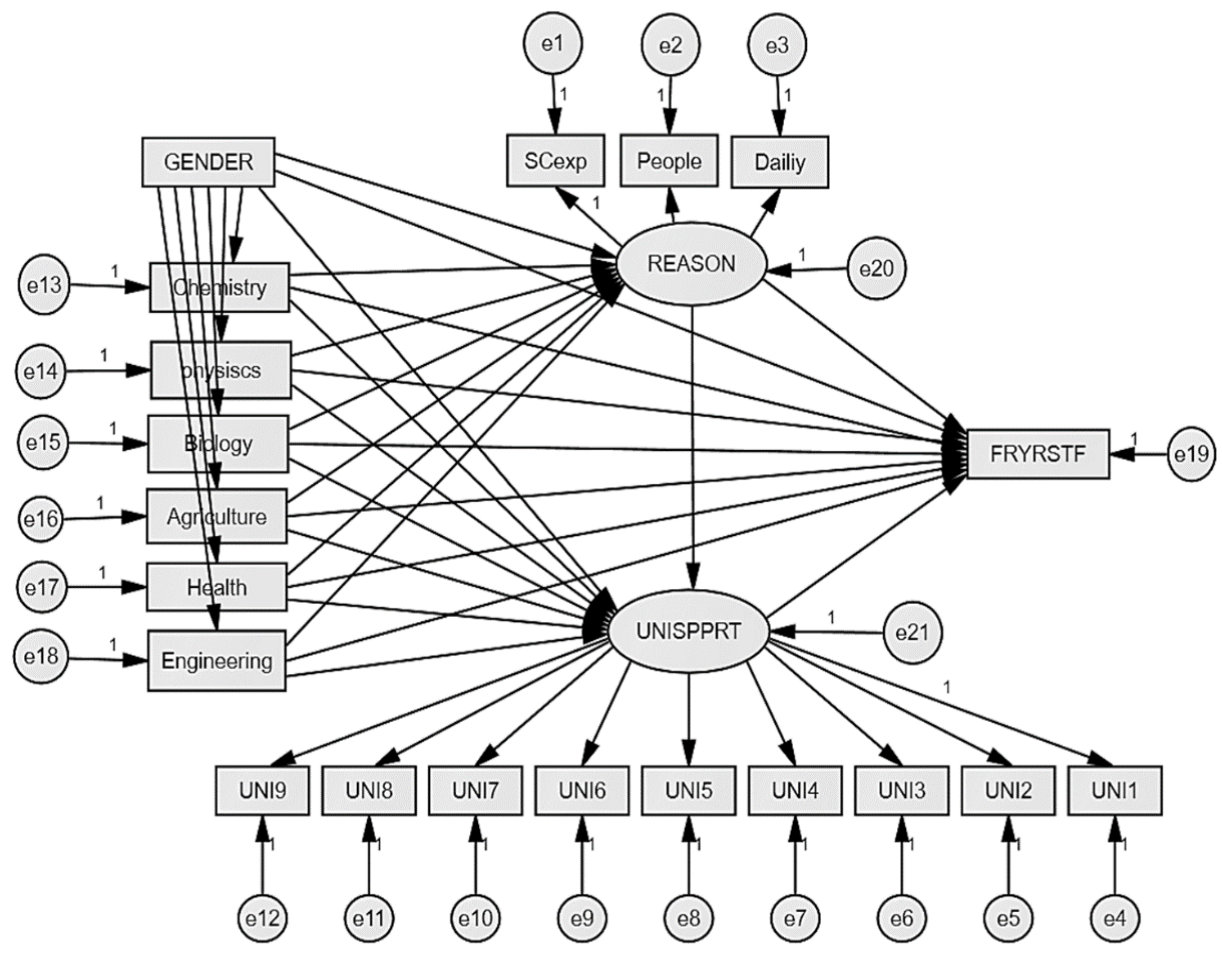

Figure 1 Hypothesized model of first year student satisfaction 
analysis, this study intended to test the good-fit of the hypothesized model.

In the hypothesized model, gender as an observed variable. The reason to participate in STEM-related subjects as a latent variable was formed from school science experience, influential others, and daily inspiration. The factor has confirmed through confirmatory factor analysis (CFA) as a single factor with RMSEA value (0.101). The program, as observed variable, consists of seven major programs. They are mathematics, chemistry, physics, biology, agriculture, health, and engineering. In the hypothesized model, mathematic did not appear because it treated like a dummy. Therefore only six programs appear. University support as a latent variable constructed from 9 items from the IRIS Q questionnaire.

\section{METHOD}

The sample $(\mathrm{N}=448)$ were first-year university students who registered in STEM-related subjects in Bandung, West Java Indonesia. The sample consists of 237 male students and 211 female students from seven major STEM-related subjects (mathematics, chemistry, physics, biology, agriculture, health, and engineering). The sample is randomly selected by distributing the online questionnaire. The sample gathered in this study was the students who voluntarily filled the online questionnaire completely.

Under the permission of IRIS International, the IRIS Q questionnaire was translated into Bahasa Indonesia by one translator. From Bahasa Indonesia, the survey was backtranslated into English by another translator to ensure consistency and minimize the loss of meaning. The final form of the questionnaire was in Bahasa Indonesia after all

Table 1 IRIS Q questionnaire

\begin{tabular}{|c|c|c|}
\hline No & Components & CODE \\
\hline & $\begin{array}{l}\text { How important was each of the following school experiences in choosing your } \\
\text { course? }\end{array}$ & School Experiences \\
\hline 1 & Your interset in related subjects & SCEXP1 \\
\hline 2 & Your previous attainment in related subjects & SCEXP2 \\
\hline 3 & Experiment/Lboratory work & SCEXP3 \\
\hline 4 & Field work/Excursions & SCEXP4 \\
\hline 5 & Lessong showing the relevance of the subject to the society & SCEXP5 \\
\hline 6 & Lesson showing practical applications of the subjects & SCEXP6 \\
\hline 7 & using mathematics in lessons & SCEXP7 \\
\hline \multirow[t]{2}{*}{8} & Clear Feedback on wheter you got the right answer & SCEXP8 \\
\hline & How important were the following persons in choosing your course? & Influential others/people \\
\hline 9 & Mother or step mother & PP1 \\
\hline 10 & Father or step father & PP2 \\
\hline 11 & Good teachers & PP3 \\
\hline 12 & Friends (Including boyfriend/girlfriend) & PP4 \\
\hline 13 & Sibling or other relatives & PP5 \\
\hline \multirow[t]{2}{*}{14} & Carriers advisor in school & PP6 \\
\hline & How important were each of the following in choosing your course? & Daily Inspiration \\
\hline 15 & Popular Science books and magazines & DLYEXP1 \\
\hline 16 & Science Fiction or fantasy book/films & DLYEXP2 \\
\hline 17 & Computer games & DLYEXP3 \\
\hline 18 & Museum/Science center & DLYEXP4 \\
\hline 19 & Popular science television program (Discovery Channel, National Geographic, etc.) & DLYEXP5 \\
\hline 20 & Film or drama on television (CSI, Numbers, Etc.) & DLYEXP6 \\
\hline 21 & Science, Technology, or Mathematics competitions & DLYEXP7 \\
\hline \multirow[t]{2}{*}{22} & Other kinds of outreach activities (e.g. Science Festivals, Science Summer Schools) & DLYEXP8 \\
\hline & $\begin{array}{l}\text { To what extend do you agree with the following statements about university } \\
\text { supports and your experiences as student so far? }\end{array}$ & $\begin{array}{l}\text { University support/ } \\
\text { experiences as student }\end{array}$ \\
\hline 23 & I enjoy the company of the other students on my course & UNI1 \\
\hline 24 & I feel I fit in socially & UNI2 \\
\hline 25 & I feel I can keep up with the pace of the teaching & UNI3 \\
\hline 26 & I get personal feedback from lectures and teachers when I need it & UNI4 \\
\hline 27 & I feel my teachers care about whether students learn or not & UNI5 \\
\hline 28 & $\begin{array}{l}\text { The university/college offers good working conditions (equipment, library, common } \\
\text { areas, cafes, technical support }\end{array}$ & UNI6 \\
\hline 29 & I can see the relevance of what I learn & UNI7 \\
\hline 30 & I feel that my course suits the kind of person that I am & UNI8 \\
\hline 31 & I have become more interested in the subject since I started & UNI9 \\
\hline
\end{tabular}


of the translators meet their agreement. The original IRIS Q comprises 65 items, but only 31 elements administered for this study (Table 1). Questions on the IRIS Q responded using a 5-point Likert Scale, ranging from 1 (Strongly Disagree) to 5 (Strongly Agree). The adapted IRIS Q consists of three components, school science experience (8 items), influential others (6 items), and daily source of inspirations (8 items) and university support/experiences as students (9 items). The adapted IRIS Q then uploaded as an online questionnaire and randomly distributed to first-year students in STEMrelated subjects by using the student's association network.

First, confirmatory factor analysis (CFA) was performed to identify underlying factors of the reason to participate in STEM-related subjects. The result showed that the constructs of the instrument are consistent with a researcher's understanding of the nature of that construct (or factor). Second, the structural equation model (SEM) analysis performed using IBM SPSS Amos 20 (Arbuckle, 2011) software to assess the causal relationships of the factors. SEM that seek the relationship between multiple variables as a member of statistical models lies in two multivariate techniques: factor analysis and multiple regression analysis (Hair, Black, Babin, \& Anderson, 2014). SEM has been widely to test the model many studies such as sociology, psychology, business and marketing, education, and many other related studies (e.g., Ahmed \& Masud, 2014; Archambault, 2008; Sembiring, 2016; Camgoz-akdag \& Zaim, 2012; Dyana \& Adeline, 2014; Elhadary, 2016a, 2016b; Gruber, Fuß, Voss, \& GläserZikuda, 2010; Ijaz, Irfan, Shahbaz, Awan, \& Sabir, 2011; Li \& Carroll, 2017). Hair, Black, Babin, \& Anderson (2014) explained there are six steps to decide on the fit model. They are: (1) define individual constructs, (2) develop overall measurement model, (3) formulate the study to produce the empirical results, (4) asses the measurement model validity, (5) specify the model, and (6) assessing structural model validity. In this study, the process of analysis was using those steps. In this study, the primary purpose of SEM is to simultaneously test the hypothesized model relationship among a set of latent constructs.

In terms of good-fit indices, this study used the standard fit indices for an SEM, which are comparative fit index (CFI), Tucker-Lewis index (TLI, or non-normed fit index), and RMSEA. The TLI and CFI values should be greater than or equal to 0.80 and the RMSEA; the value should be between 0.08 to 0.10 to get mediocre fit (Hooper, Coughlan, \& Mullen, 2008). It should also be considered that there should be justification for the group of fit indices provided, it should converge to a conclusion that the data fit the sample model and also it is very crucial to determine the overall fit from multiple indices and not just a single fit index (Schreiber, 2008).

Furthermore, the model Chi-square value and degrees of freedom should also be reported because some fit indices are based on those values but are not typically used to justify the fit of the data to the model because of the Chi-square value is sensitive to sample size (Schreiber, 2008). At last, to be considered is because of the volume of fit indices, it becomes a temptation to choose the best-fit indices that indicate the best fit. It is should also be avoided at all costs removing important just because only based on the cut-off of fit indices. As a way to improve model fit, it is good practice to check the fit of each construct and its items individually to specify whether there are any poor items (Hooper, Coughlan, \& Mullen, 2008). At last, SEM is an a priori method; therefore, the removal or addition of a relationship during model modification must consider theoretical, not just statistical sense. Because modifying using statistical results may lead to producing a nonrepresentative model from the actual data (Schreiber, 2008)

\section{RESULT AND DISCUSSION}

The hypothesized model was tested by following the procedure to test the good-fit of the model (Hair, Black, Babin, \& Anderson, 2014). There were seven tested models to find the good-fit of the model (Table 2). The hypothesized model has not fit the actual data with TLI value (0.499), CFI Value (0.610), and RMSEA value (0.136). Then, to improve the good-fit of the model, the insignificant relationships indicated by $\mathrm{p}$-value higher than 0.05 were excluded in the hypothesized model to form tested model 1. In this model (gender to satisfaction=0.952), (dummy2 to university support $=0.717)$, (gender to university support $=0.999)$, (dummy 7 to reason $=0.837)$, (gender to reason $=0.777$ ), and (dummy5 to reason=0.806). After modification, tested model 1 showed better fit to the actual data indicated by

Table 2 Good-fit index for the tested models ( $\mathrm{n}=448)$

\begin{tabular}{llllllllll}
\hline No & Model & \multirow{2}{*}{ CMIN } & df & CMIN/df & NFI & RFI & TLI & CFI & RMSEA \\
\hline 1 & Hypothesized model & 1380.115 & 148 & 9.325 & 0.588 & 0.471 & 0.499 & 0.610 & 0.136 \\
2 & Tested model 1 & 1380.291 & 154 & 8.963 & 0.588 & 0.492 & 0.521 & 0.612 & 0.133 \\
3 & Tested model 2 & 1383.545 & 161 & 8.593 & 0.587 & 0.513 & 0.543 & 0.613 & 0.130 \\
4 & Tested model 3 & 1038.124 & 147 & 7.062 & 0.653 & 0.597 & 0.633 & 0.684 & 0.116 \\
5 & Tested model 4 & 1045.640 & 151 & 6.925 & 0.651 & 0.605 & 0.641 & 0.683 & 0.115 \\
6 & Tested model 5 & 815.730 & 150 & 5.438 & 0.728 & 0.690 & 0.731 & 0.764 & 0.100 \\
7 & Tested model 6 & 294.278 & 63 & 4.671 & 0.876 & 0.847 & 0.875 & 0.899 & 0.091 \\
\hline
\end{tabular}


Table 3 Factor loading of factor in the good-fit models

\begin{tabular}{lcll}
\hline \multicolumn{2}{l}{ Factor Loading } & & Estimate \\
\hline UNISPPRT & $<---$ & REASON & .556 \\
SCexp & $<---$ & REASON & .679 \\
People & $<---$ & REASON & .554 \\
Dailiy & $<---$ & REASON & .617 \\
UNI1 & $<---$ & UNISPPRT & .543 \\
UNI2 & $<---$ & UNISPPRT & .572 \\
UNI3 & $<---$ & UNISPPRT & .728 \\
UNI4 & $<---$ & UNISPPRT & .587 \\
UNI5 & $<---$ & UNISPPRT & .530 \\
UNI6 & $<---$ & UNISPPRT & .469 \\
UNI7 & $<---$ & UNISPPRT & .677 \\
UNI8 & $<---$ & UNISPPRT & .832 \\
UNI9 & $<---$ & UNISPPRT & .787 \\
FRYRSTF & $<---$ & UNISPPRT & .615
\end{tabular}

TLI value (0.521), CFI Value (0.612), and RMSEA value (0.133) but still has not met the required fit indices.

Tested model 1 then further analyzed to identify the insignificant relationship. To improve the model fit, insignificant in this model were excluded to form tested model 2 (dummy2 to reason=0.300), (dummy7 to university $\quad$ support $=0.498), \quad($ dummy3 to satisfaction $=0.699), \quad($ dummy 2 to satisfaction $=0.486)$, (dummy5 to satisfaction=0.641), $\quad($ dummy6 to satisfaction $=0.621$ ) and (dummy7 to satisfaction $=0.806$ ). After modification, tested model 2 showed better fit to the actual data indicated by TLI value (0.543), CFI Value
(0.613), and RMSEA value (0.130) but still has not met the required fit indices.

Tested model 2 further modified to improve the model fit by exclude the insignificant relationship to form tested model 3, they were (dummy4 to satisfaction=0.177), (reason to satisfaction $=0.115$ ), (dummy6 to university support $=0.153$ ), (gender to dummy2=0.108), (dummy2 to reason=0.276), and (dummy6 to university support=0.153). After modification, tested model 3 showed better fit to the actual data indicated by TLI value (0.633), CFI Value (0.684), and RMSEA value (0.116) but still has not met the required fit indices.

Tested model 3 further modified to improve the model fit by excluding the insignificant relationship to form tested model 4, they were (dummy4 to satisfaction $=0.177$ ), (reason to satisfaction $=0.115),($ dummy6 to reason $=0.193)$, (dummy 3 to university support $=0.150)$ and $($ dummy 4 to university support=0.144). After modification, tested model 4 showed better fit to the actual data indicated by TLI value (0.641), CFI Value (0.683), and RMSEA value (0.115) but still has not met the required fit indices.

They tested model 4 further modified to improve the model fit by excluding the insignificant relationship (dummy3 to university support $=0.352$ ) to form tested model 5. After modification, tested model 5 showed better fit to the actual data indicated by TLI value (0.731), CFI Value (0.764), and RMSEA value (0.100) but still has not met the required fit indices.

Tested model 5 further modified to improve the model fit by excluding the insignificant relationship, but in this model, the relationships were all significant. To improve

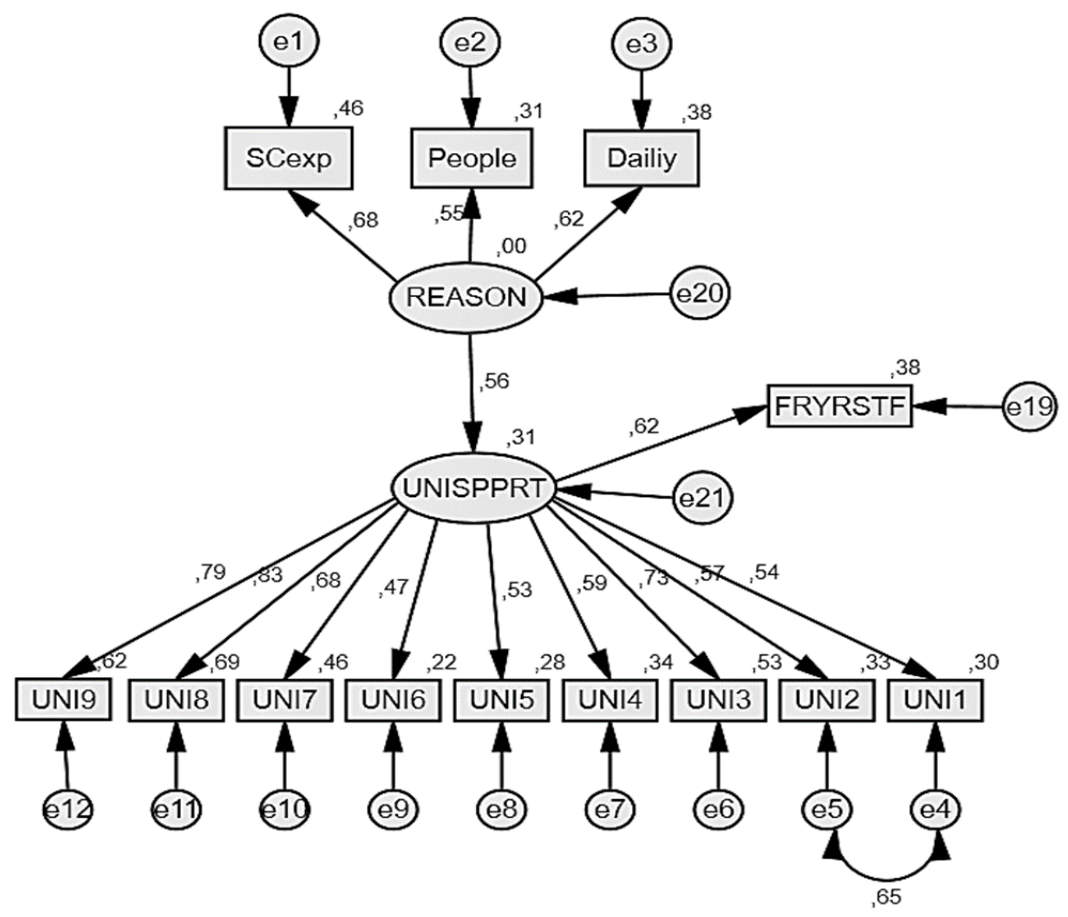

Figure 2 Final model of first year student satisfaction (standardized) 
the model by considering closely related errors, the author correlated error 4 and error 5 because of both of the highly correlated. The author also excluded gender and program because they were not significantly having a direct effect on student satisfaction confirmed by an independent sample t-test and one-way ANOVA. An independent sample t-test showed that there were no significant differences of satisfaction between male $(\mathrm{M}=10.01 ; \mathrm{SD}=1.90)$ and female $(\mathrm{M}=9.99 ; \mathrm{SD}=1.82 ; \mathrm{t}(446)=1.62, \mathrm{p}=0.90$, two-tailed $)$. While program also showed that there was no significant difference at the $\mathrm{p}<.05$ in the groups: $\mathrm{F}(6,441)=0.74, \mathrm{p}=$ 0.62. Mathematics $(\mathrm{M}=10.03 ; \mathrm{SD}=1.56)$, Chemistry $(\mathrm{M}=10.40 ; \mathrm{SD}=1.98)$, Physics $(\mathrm{M}=9.85 ; \mathrm{SD}=1.50)$, Biology $(\mathrm{M}=10.50 ; \mathrm{SD}=1.89)$, Agriculture $(\mathrm{M}=9.86 ; \mathrm{SD}=2.05)$, Health $(\mathrm{M}=9.91 ; \mathrm{SD}=1.92)$ and Engineering $(\mathrm{M}=10.00$; $\mathrm{SD}=1.86)$. After modification, tested model 6 showed better fit to the actual data indicated by TLI value (0.875), CFI Value (0.899), and RMSEA value (0.091) and also met the requirement for model fit to the actual data (figure 2).

All of the factor loadings in the tested model 6 met the minimum requirement (0.32), as can be seen in table 3 . (Hair, Black, Babin, \& Anderson, 2014). That signified that construct validity is adequate. The model also showed that reason, and university support indirectly explained 38\% of the total variances of student's satisfaction and reason explained $31 \%$ of total variations of university supports. In this case, the model can consider contributing to the planning of the university program.

This study explored the relationship gender, reasons to participate in STEM-related subjects, programs, and the university supports on first-year university student's satisfaction. The SEM results showed that students' satisfaction with STEM learning is highly affected by university supports (experiences as a student) which is consistent with previous studies that university supports highly correlated with student's overall satisfaction (Crisp et al., 2009; Green, Hood, \& Neumann, 2015; Gruber, Fuß, Voss, \& Gläser-Zikuda, 2010; Hakim, 2014; Lo, 2010; Suarman, Aziz, \& Yasin, 2013; Wilkins, Balakrishnan, \& Huisman, 2012). This result confirms and strengthens the fact that student satisfaction can be used as indicators to identify the areas where the university is performing well. Moreover, it can also apply for performing strategies to retain and fit the students, providing insights or reputation of the university from people, and providing feedback for future program planning (Billups, 2008).

Gender and program are excluded in the model because both showed no difference in terms of satisfaction confirmed by independent sample t-test and one-way ANOVA, so it is unnecessary to control the effect from the model. This finding also consistent with the previous study that gender and program do not have a significant influence on student's satisfaction (Elhadary, 2016a). Female students put higher expectations and demands on the importance of university services than male students (Grebennikov \& Skaines, 2009).

In the model, UNI1 and UNI2 are highly correlated; this is because after checking the items, the statements from both items are asking quite a similar question. UNI1 (I enjoy the company of the other students on my course) and UN2 (I feel I fit in socially). Both of them asking the social life and interaction of the student.

The model also showed that reason and university support indirectly explained $38 \%$ of the total variances of student's satisfaction and reason itself explained $31 \%$ of total variations of university supports. In this case, the higher the reason, the more the students need university support, and the more the university supports the students, the more they feel satisfied. This finding is in line with the previous research that highlight the more the university helps the students the more they feel satisfied (Al-Sheeb, Hamouda, \& Abdella, 2018; Son, Ha, Thi, \& Khuyen, 2018; Burgess, Senior, Moores, 2018; Khalil-Ur-Rehman, Farooq, \& Younas, 2018: Tandilashvili, 2019). Knowing this finding, the university needs to manage the students as customers by providing the supports which able to prepare the students for successful carrier and worthy employment after graduation. Seem like the business industry, which depends on customer satisfaction. When the students satisfied with the university, indirectly, they will share and encourage people to choose the programs that make them satisfied. If the university is able to achieve it, it is also indicating that the university is performing well to provide education that fit the students and the society in general.

\section{CONCLUSION}

This study is an exploratory way using SEM that was conducted based on data obtained from students in STEMrelated subjects in West Java Province. As a result, it should be considered to confirm if the final model in this study can be generalized to other university students in general. For the next future studies, it is essential to verify the existence of the model constructs and the structural relationships between constructs using the data obtained from other university students to generate a better generalization.

\section{ACKNOWLEDGMENT}

The author would like to thanks Ellen K. Henriksen for permission to adapt the IRIS Q instrument and Che Yee Lye and AAI Awardees 2017 for their helpful lessons, advice, and supports during the data analysis.

\section{REFERENCES}

Ahmed, S., \& Mehedi Masud, M. (2014). Measure Service Quality of a Higher Educational Institute towards Student Satisfaction. American Journal of Educational Research, 2(7), 447-455. https://doi.org/10.12691/education-2-7-3

Al-Sheeb, B., Hamouda, A. M., \& Abdella, G. M. (2018). Investigating Determinants of Student Satisfaction in the First Year of College 
in a Public University in the State of Qatar. Education Research International, 2018(1-14). https://doi.org/10.1155/2018/7194106

Arbuckle, J. L. (2011). IBM SPSS AMOS. Chicago: SPSS.

Archambault, L. Z. (2008). Measuring Service Performance, Student Satisfaction and its Impact on Student Retention in Private, PostSecondary Institutions. EDU-COM International Conference. Sustainability in Higher Education: Directions for Change., (November), 19-21. Retrieved from http://ro.ecu.edu.au/ceducom/2

Billups, F. D. (2008). Measuring College Student Satisfaction: A MultiYear Study of the Factors Leading to Persistence Measuring College Student Satisfaction: A Multi-Year Study of the Factors Leading to Persistence. NERA Conference Proceedings, Paper 14. Retrieved from http://digitalcommons.uconn.edu/nera 2008\%5Cnhttp://digital commons.uconn.edu/nera 2008/14

Burgess, A., Senior, C., \& Moores, E. (2018). A 10-year case study on the changing determinants of university student satisfaction in the UK. PLOS ONE, 13(2), 1-15. https://doi.org/10.1371/journal.pone.0192976

Camgoz-akdag, H., \& Zaim, S. (2012). Education: a comparative structural equation modeling study. Procedia - Social and Behavioral Sciences, $\quad 47, \quad$ 874-880. https://doi.org/10.1016/j.sbspro.2012.06.750

Chang, Y., \& Park, S. W. (2014). Exploring Students' Perspectives of College STEM: An Analysis of Course Rating Websites. International Journal of Teaching and Learning in Higher Education, 26(1), 90-101. Retrieved

from http://www.eric.ed.gov.proxy.library.msstate.edu/contentdelivery / servlet $/$ ERICServlet?accno=EJ1043017

Crisp, G., Palmer, E., Turnbull, D., Nettelbeck, T., Ward, L., LeCouteur, A., ... Schneider, L. (2009). First year student expectations: Results from a university-wide student survey. Journal of University Teaching and Learning Practice, 6(1), 13-26. Retrieved from http://ro.uow.edu.au/jutlp/vol6/iss1/3

Douglas, J., Douglas, A., \& Barnes, B. (2006). Measuring student satisfaction at a UK university. Quality Assurance in Education, 14(3), 251-167.

Duong, M.-Q. (2015). The Factors Influencing Student Satisfaction in Vietnamese Higher Education. International Research in Education, 4(1), 27. https://doi.org/10.5296/ire.v4i1.8191

Dyana, M. L., \& Adeline, Y. L. (2014). Student satisfaction with the service quality of cafeteria: a structural approach, 4(1), 105-111.

Elhadary, O. (2016a). Gender and other Determinants of Undergraduate Student Satisfaction in STEM, 15(3), 256-264

Elhadary, O. (2016b). Student Satisfaction in STEM : An Exploratory Study, 4(2), 195-199. https://doi.org/10.12691/education-4-2-7

Grebennikov, L., \& Skaines, I. (2009). Gender and higher education experience: A case study. Higher Education Research \& Development, 28(1), 71-84. https://doi.org/10.1080/07294360802444370

Green, H. J., Hood, M., \& Neumann, D. L. (2015). Predictors of student satisfaction with university psychology courses: A review. Psychology Learning and Teaching, 14(2), 131-146. https://doi.org/10.1177/1475725715590959

Gruber, T., Fuß, S., Voss, R., \& Gläser-Zikuda, M. (2010). Examining student satisfaction with higher education services. International Journal of Public Sector Management, 23(2), 105-123. https://doi.org/10.1108/09513551011022474

Hair, J. F., Black, W. C., Babin, B. J., \& Anderson, R. E. (2014). Multivariate data analysis (7th ed.). Harlow: Pearson Education Limited.

Hakim, A. (2014). Nursing students' satisfaction about their field of study. Journal of Advances in Medical Education \& Professionalism, 2(2), 82-7. Retrieved from http:/ / www.pubmedcentral.nih.gov/articlerender.fcgi?artid=4235 $554 \&$ tool $=$ pmcentrez\&rendertype $=$ abstract

Hooper, D., Coughlan, J., \& Mullen, M. (2008). Structural Equation Modelling: Guidelines for Determining Model Fit Structural equation modelling : guidelines for determining model fit. Electronic Journal of Business Research Methods, 6(1), 53-60. https://doi.org/10.1037/1082-989X.12.1.58

Ijaz, A., Irfan, S. M., Shahbaz, S., Awan, M., \& Sabir, M. (2011). An empirical model of student satisfaction : case of pakistani public sector business schools, $V I I(\mathrm{Ii}), 91-116$.

Josephat, P., Ismail, A., \& Martin, P. (2014). Undergraduate Students ' Satisfaction Survey at the University of Dodoma, 3(2), 45-53.

Khalil-Ur-Rehman, F., Farooq, M., \& Younas, W. (2018). Investigating the Factors Impacting the Student Satisfaction with the Universities In the Era of Artificial Intelligence: A Comparative Study of Malaysia and Pakistan. The Journal of Social Sciences Research, 2(3), 5-9. https://doi.org/10.31580/apss.v2i3.221

Li, I. W., \& Carroll, D. R. (2017). Factors Influencing University Student Satisfaction, Dropout and Academic Performance, 56.

Lo, C. (2010). How Student Satisfaction Factors Affect Perceived Learning. Journal of the Scholarship of Teaching and Learning, 10(1), 47$54 . \quad$ Retrieved from http://www.eric.ed.gov/ERICWebPortal/recordDetail?accno $=\mathrm{E}$ J882125

Mehdipour, Y., \& Zerehkafi, H. (2013). Student Satisfaction at Osmania University. International Journal of Advancements in Research \& Technology, 2(6), 233-240.

Möller, O. (2006). Student satisfaction survey: The Utrecht University approach. Tertiary Education and Management, 12(4), 323-328. https://doi.org/10.1007/s11233-006-9009-0

Naaj, M. A., Nachouki, M., \& Ankit, A. (2012). Evaluating Student Satisfaction with Blended Learning in a Gender-Segregated Environment. Journal of Information Technology Education: Research, 11, 185-200. Retrieved from http://www.jite.org/documents/Vol11/JITEv11p185200AbouNaaj0979.pdf

Pawson, C. (2012). HEA STEM Conference STEM vs . non-STEM programmes. Psychology Teaching Review, 18(2), 16-21.

Schreiber, J. B. (2008). Core reporting practices in structural equation modeling. Research in Social and Administrative Pharmacy, 4(2), 83-97. https://doi.org/10.1016/j.sapharm.2007.04.003

Sembiring, M. G. (2016). Student Satisfaction and Persistence: Imperative Features for Retention in Open and Distance Learning. Asian Association of Open Universities Journal, 10(1), 1-11.

Shulman, L. s. (1987). Knowledge and teaching: Foundations of the new reform. Harvard Educational Review, 57(1), 1-22.

Suarman, Aziz, Z., \& Yasin, R. M. (2013). The quality of teaching and learning towards the satisfaction among the university students. Asian Social Science, $9(12$ SPL ISSUE), 252-260. https://doi.org/10.5539/ass.v9n12p252

Son, H. T., Ha, N. T., Thi, P., \& Khuyen, M. (2018). Measuring Students' satisfaction with higher education service-An experimental study at Thainguyen University. Www.Ijbmm.Com International Journal of Business Marketing and Management, 3(4), 2456-4559. Retrieved from www.ijbmm.com

Tandilashvili, N. (2019). Education. The Case of a Georgian State University. In RAIS Conference Proceedings (pp. 39-54). https://doi.org/10.5281/zenodo.3267486

Wilkins, S., Balakrishnan, M., \& Huisman, J. (2012). Student satisfaction and student perceptions of quality at international branch campuses in the United Arab Emirates. Journal of Higher Education Policy and Management, 34(5), 543-556. https://doi.org/10.1080/1360080X.2012.716003

Zhou, H. (2016). Empirical Study on University Curriculum Satisfaction of University Graduates. Open Journal of Social Sciences, 4(January), 132-137. 